\title{
PULMONARY VASCULAR EFFECTS OF ACETYLSALICYLIC ACID, CHLOROQUINE, DEXTRAN AND METHYLPREDNISOLONE GIVEN AFTER HAEMORRHAGIC SHOCK IN DOGS
}

\author{
William H. Noble, Christopher E. Famewo, and M. Bernadette Garvey
}

MaNr stunies have been performed which indicate a lung lesion occurs after severe haemorrhagic shock in cats, ${ }^{1}$ dogs, ${ }^{2-6}$ pigs, ${ }^{2}$ rabbits, ${ }^{7}$ monkeys ${ }^{8}$ and baboons. ${ }^{0}$ Lung lesions after haemorrhagic shock have also been reported in humans ${ }^{10}$ but these have been complicated by other problems such as blast injury, fat embolism, chest trauma, or oxygen toxicity. However, these cases give credence to the idea that the lung lesions found after haemorrhagic shock in animals occur in humans as well.

In animals two findings have been characteristic of the lung after haemorrhagic shock. These are pulmonary interstitial oedema $a^{2,3,8,11}$ and increased pulmonary vascular resistance. ${ }^{1,2,6,12-14}$ Interstitial oedema has been found both in vitro by light and electron microscopic examinations $s^{3,8,0,11}$ and in vivo by a double indicator dilution technique. ${ }^{2}$ The increased pulmonary vascular resistance (PVR) after haemorrhagic shock has been related to mixed venous $\mathrm{pH}^{12}\left(\mathrm{pH}_{v}\right)$ but even after $\mathrm{pH}_{v}$ was corrected to control values ${ }^{2,12}$ PVR was still increased 100 per cent. Platelet aggregates or the substances they release have been implicated as a cause of the increased PVR.

Since interstitial oedema and increased PVR occur together after haemorrhagic shock, one may potentiate the other. Oedema formation may be reduced by preventing the increased PVR. Famewo, et al. ${ }^{15}$ found that acetylsalicylic acid (A.S.A.) given to dogs through a stomach tube before the shock period reduced the increase of PVR and lowered the increase in lung water after shock. Since patients cannot be given A.S.A. before their period of shock the question remained whether A.S.A. given intravenously after the shock period would have the same beneficial effect on the lung.

The influence of A.S.A. on PVR may be through reduction of platelet aggregation, thus preventing platelet emboli from obstructing the pulmonary microvasculature; ${ }^{10}$ or by preventing extrusion of platelet components which cause pulmonary vasoconstriction and/or increased capillary permeability; ${ }^{17}$ or by protecting the lung from toxic substances released during shock; or the effect may not be related to platelet changes, but to a non-specific effect such as membrane stabilization, so that a pulmonary vasoconstrictor mechanism does not function. In an attempt to determine which of these possibilities is correct and at the same time to find the best drug to prevent the increased PVR and interstitial oedema

William H. Noble, B.A., M.D., D.A., F.R.C.P.(C), Christopher E. Famewo, M.B., B.S., D.A., F.R.C.P.(C), Department of Anaesthesia, and M. Bernadette Garvey, B.Sc., M.D., F.R.C.P.(C), Division of Haematology, Department of Medicine, St. Michael's Hospital and University of Toronto, Toronto, Ontario, Canada. 
after haemorrhagic shock, we tested drugs with very different effects in the same shock lung model.

Low molecular weight dextran 40 (Rheomacrodex in NS., Pharmacia, Uppsala, Sweden), which reduces platelet aggregation ${ }^{18}$ and increases blood volume, was infused after haemorrhagic hypotension and before re-infusion of blood in dogs. Similarly methylprednisolone, which has a membrane stabilizing effect, was given to another group of dogs. Finally chloroquine, with a mild platelet anti-aggregating effect, ${ }^{19}$ was given to yet another group of dogs.

\section{Methons}

Five similar groups of dogs were studied. There were five dogs in each group. Anaesthesia was induced and maintained with intravenous pentabarbitone (20-30 $\mathrm{mg} / \mathrm{kg}$ initially with supplements as necessary to maintain light anaesthesia). A tracheostomy was done. The animals breathed air spontaneously while lying supine. Femoral arterial and venous catheters were inserted for pressure monitoring and for withdrawal or infusion of blood. A flexible injection catheter was floated into the pulmonary artery. ${ }^{20} \mathrm{~A}$ central venous pressure (CVP) catheter was inserted. A left atrial catheter was inserted from the internal carotid artery. ${ }^{20}$ Finally, a special aortic sensing catheter for temperature and blood electrical conductivity was passed up a femoral artery to the arch of the aorta to measure extravascular thermal volume of the lung ( ETV $_{\mathrm{L}}$, a measure of lung water)..21,22 Catheters were kept patent by flushing with normal saline and no heparin was used.

The thermodilution method $\left(\mathrm{ETV}_{\mathrm{L}}\right)$ was used to measure lung water, cardiac output $(\dot{Q})$, and central blood volume (CBV). ${ }^{21}$ Systemic vascular resistance and PVR were calculated, where

$$
\mathrm{PVR}=(\overline{\mathrm{PA}}-\overline{\mathrm{LA}} / \dot{\mathrm{Q}}) \times 1332
$$

(PVR is in dynes.sec.cm ${ }^{-5}, \overline{\mathrm{PA}}$ is mean pulmonary artery pressure and $\overline{\mathrm{LA}}$ is mean left atrial pressure in $\mathrm{mm} \mathrm{Hg}$, and $Q$ is in $\mathrm{ml} / \mathrm{sec}$.)

The animals breathed through a low resistance Lloyd non-rebreathing valve and mixed expired gas was collected for oxygen and carbon dioxide analysis. At the same time mixed venous blood from the pulmonary artery line and femoral arterial blood were taken for blood gas analysis. These values allowed shunt fraction (Qs/Qt) and VD/VT $/ 24$ to be calculated.

The experiment was conducted as follows. Control values were determined four times. Blood was then removed to ACD blood packs to keep the mean arterial pressure between $40-50 \mathrm{~mm} \mathrm{Hg}$ for at least two hours. Blood was withdrawn under aseptic conditions through standard plastic blood withdrawal sets into ACD blood packs (Fenwal Laboratories). The blood did not contact air. Measurements were continued in the shock period. At the end of the shock period all the blood was re-infused and the measurements were repeated. Blood was re-infused through a plastic coil (Travenol Laboratories, N.C.) to allow warming to the dog's temperature and through a standard blood filter (Baxter Laboratories of Can. Ltd.) to reduce any cellular trauma which might occur as blood passed through a 
NOBLE, et al.: PULMONARY EFFECTS OF DRUCS AFTER HAEMORRHAGIC SHOCK 663

micropore filter. ${ }^{25} \mathrm{NaHCO}_{3}$ was then infused to return the Base excess (B.E.) to control values. Measurements were repeated until B.E. was at control values, usually requiring 45 minutes.

A complete blood coagulation screen was done during the control period, at the beginning and at the end of the period of shock and after $\mathrm{NaHCO}_{3}$ was infused at the end of the experiment. The coagulation screen included an assay of individual coagulation factors and measurement of fibrin break-down products. Platelet aggregation was measured using a Payton aggregometer and Bausch and Lomb recorder.

The animals were divided into five groups. One group remained as control and received no drugs. A second group received $900 \mathrm{mg}$ of A.S.A. in an intravenous preparation (Aspegic, Laboratoire Egic, France) at the end of shock, before re-infusion of blood. A third group was given chloroquine $200 \mathrm{mg}$ intramuscularly before the shock period. A fourth group received low molecular weight dextran 40,10 per cent in normal saline, just before blood was re-infused. This represents an extra fluid load, therefore $500 \mathrm{ml}$ of blood was not re-infused while $250 \mathrm{ml}$ of dextran was given. The final group received methylprednisolone $30 \mathrm{mg} / \mathrm{kg}$ intravenously after shock, before re-infusion of blood.

Salicylate blood levels were determined at the end of the experiment in the group that received intravenous A.S.A. Chloroquine blood levels were determined at the end of the experiment in the dogs receiving chloroquine.

Statistical analysis was carried out using Student's t-test for paired data when comparing data in the same dog and for independent samples when comparing data between groups of dogs. ${ }^{26}$ Results were considered statistically significant when $\mathrm{p}<0.05$. N.S. indicates changes which were not statistically significant. \pm indicates S.E.M.

\section{RESULTS}

Since the "no drug" group behaved the same as the experimental groups during the control and shock periods, data are presented as pooled data for the control and shock periods (Tables I and III). The "no drug" group also behaved the same as a larger control group previously reported. ${ }^{2}$ As blood was removed mean arterial pressure (M.A.P.), central venous pressure (C.V.P.), pulmonary artery pressure (P.A.), left atrial (L.A.) pressure and cardiac output ( $\dot{Q}$ ) fell (Figure 1 and Table I). Between the early and late periods of hypotension, however, pulmonary artery pressure (PA) rose significantly $(7 \pm 2 \mathrm{~mm} \mathrm{Hg}, \mathrm{p}<0.025)$ while left atrial pressure fell $(1.4 \pm 0.5 \mathrm{~mm} \mathrm{Hg}, \mathrm{p}<0.025)$ (Figure 1), CVP fell $(0.8 \pm$ $0.3 \mathrm{~cm} \mathrm{H}_{2} \mathrm{O}, \mathrm{p}<0.01$ ) and mean arterial pressure did not change (early shock $54 \pm 3 \mathrm{~mm} \mathrm{Hg}$ and late shock $52 \pm 1 \mathrm{~mm} \mathrm{Hg}$ ).

Between the early and late hypotensive period the mean pulmonary artery to left atrial pressure gradient rose $9.5 \pm 1.7 \mathrm{~mm} \mathrm{Hg}(\mathrm{p}<0.005)$ (Figure 1). This, along with a slight fall in $\dot{Q}(0.26 \pm 0.08 \mathrm{l} / \mathrm{min}, \mathrm{p}<0.01)$, resulted in a $74.9 \pm$ 11.9 per cent increase in PVR ( $p<0.001$, Figures 1 and 2$)$. During the hypotensive period $\mathrm{pH}$ fell $(0.099 \pm 0.021, \mathrm{p}<0.001)$ due to a metabolic acidosis as B.E. fell (7.17 $\pm 0.79 \mathrm{mEq} / \mathrm{l}, \mathrm{p}<0.001) . \mathrm{Pa}_{\mathrm{O}_{2}}$ rose $(13.5 \pm 1.9 \mathrm{~mm} \mathrm{Hg}, \mathrm{p}<0.001)$ as the 


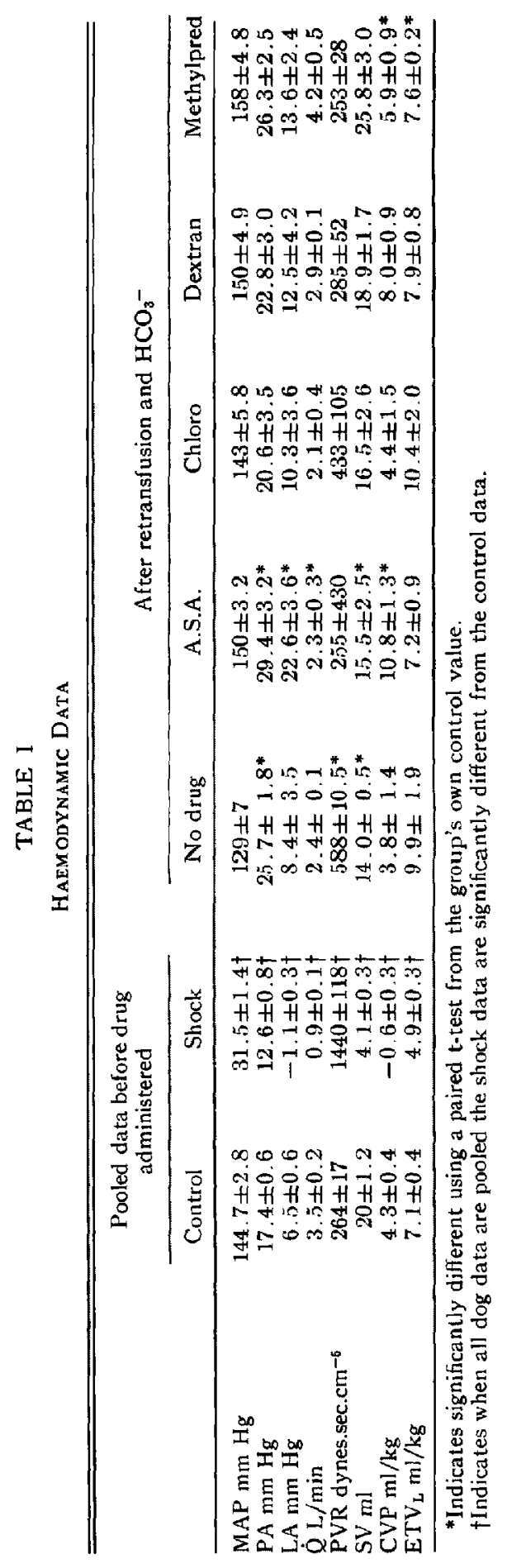


NOBLE, et al.: PULMONARY EFFECTS OF DRUGS AFTER HAEMORRHAGIC SHOCK

TABLE II

Haemodynamic Changes in the Five Groups of Dogs

\begin{tabular}{|c|c|c|c|c|c|}
\hline & No drug & A.S.A. & Chloroquine & Dextran & Methylpred \\
\hline$\triangle \mathrm{PA} \mathrm{mm} \mathrm{Hg}$ & $\begin{array}{l}+9.3^{*} \\
\pm 1.09\end{array}$ & $\begin{array}{c}+11.8^{*} \\
\pm 2.9\end{array}$ & $\begin{array}{l}+2.4 \\
\pm 3.9\end{array}$ & $\begin{array}{l}+7.2 \\
\pm 3.1\end{array}$ & $\begin{array}{l}+7.8 \\
\pm 3.0\end{array}$ \\
\hline$\Delta \mathrm{LA} \mathrm{mm} \mathrm{Hg}$ & $\begin{array}{l}+3.2 \\
\pm 3.7\end{array}$ & $\begin{array}{c}+16.6^{*} \dagger \\
\pm 3.0\end{array}$ & $\begin{array}{l}+5.2 \\
\pm 4.0\end{array}$ & $\begin{array}{l}+7.7 \\
\pm 3.5\end{array}$ & $\begin{array}{l}+6.1 \\
\pm 2.5\end{array}$ \\
\hline$\Delta \dot{Q} \mathrm{~L} / \mathrm{min}$ & $\begin{array}{l}-0.75 \\
\pm 0.24\end{array}$ & $\begin{array}{l}-1.47^{*} \\
\pm 0.32\end{array}$ & $\begin{array}{l}-1.09 \\
\pm 0.71\end{array}$ & $\begin{array}{l}-0.10 \\
\pm 0.32\end{array}$ & $\begin{array}{l}-0.49 \\
\pm 0.68\end{array}$ \\
\hline$\Delta$ PVR dynes.sec. $\mathrm{cm}^{-6}$ & $\begin{array}{l}+284^{*} \\
\pm 69.9\end{array}$ & $\begin{array}{c}-9.1 \dagger \\
\pm 55.7\end{array}$ & $\begin{array}{l}+184.8 \\
\pm 103.8\end{array}$ & $\begin{array}{l}-8.5 \dagger \\
\pm 87.6\end{array}$ & $\begin{array}{l}+30.4 \dagger \\
\pm 36.7\end{array}$ \\
\hline
\end{tabular}

*Means significantly different from its own control value.

$\dagger$ Means significantly different from the control "no drug" group.

$\Delta \mathrm{Is}$ the change from the group's own control to after $\mathrm{NaHCO}_{3}$ infusion.

dog hyperventilated. ${ }^{2}$ In spite of hyperventilation and an increased PVR, VD/VT did not change from early shock to late shock.

\section{No drug group}

In the "no drug" or control group after blood was re-transfused left atrial pressure returned to control levels (Figure 1, Tables I and II). Along with a return of $\dot{Q}$ to control values (Figure 1 and Table II) this meant that PVR remained significantly elevated above control $(93.1 \pm 13.4$ per cent, $p<0.005)$ even after $\mathrm{NaHCO}_{3}$ was infused $(94.8 \pm 17.3$ per cent $\mathrm{p}<0.01)$ to correct the metabolic acidosis which developed during shock (Figures 2 and 3, Table I). There was no significant difference between the groups of dogs in the amount of $\mathrm{NaHCO}_{3}$ given to correct the acidosis. The "no drug" group received $46.2 \pm 8.2 \mathrm{mEq}$. The only other significant changes in the "no drug" group from control period to after $\mathrm{NaHCO}_{3}$ infusion period were; VD/VT increased, $\mathrm{A}-\mathrm{aO} 2$ gradient increased $146 \pm$ 57 per cent $(\mathrm{p}<0.01), \mathrm{Pv}_{\mathrm{O}_{2}}$ fell (Table III) and stroke volume fell (Table I). In spite of a reduced platelet count after shock in every control dog, the fall did not reach the level of significance. Lung water, as measured by the $\mathrm{ETV}_{\mathrm{r}}$ technique, had a mean increase of 25 per cent (N.S., Table IV) from control to after $\mathrm{NaHCO}_{3}$. In a larger group of control dogs ETV $_{\mathbf{I}}$ did significantly increase 34 per cent over the same experiment and times. ${ }^{2}$

\section{Intravenous acetylsalycilic acid group}

Figure 2 indicates that the PVR changes during shock in the dogs who later received A.S.A. are not different from the control dogs. After A.S.A. is given, however, PVR is reduced to control levels and significantly below "no drug" dogs ( $p<$ 0.001 ) (Figures 2 and 3, Table II). While pulmonary artery and left atrial pressures rose, from control to after $\mathrm{NaHCO}_{3}$ in the dogs receiving intravenous A.S.A. (Table I) the mean gradient of pressure from pulmonary artery to left atrium fell, although not significantly. This, along with a fall in $\dot{Q}$, resulted in the unchanged PVR at the end of the experiment in the dogs receiving intravenous A.S.A. (Tables I and II). In spite of the elevated pumonary and left atrial pressures, ETV $\mathrm{I}_{\mathrm{J}}$ did 


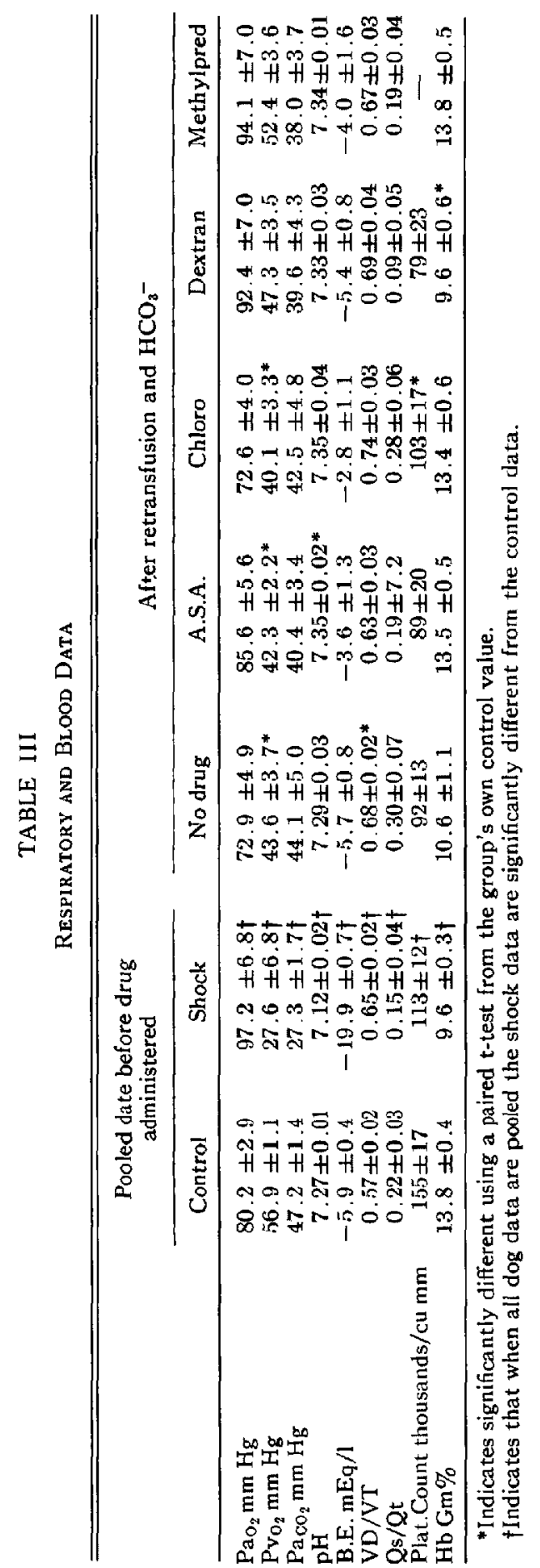




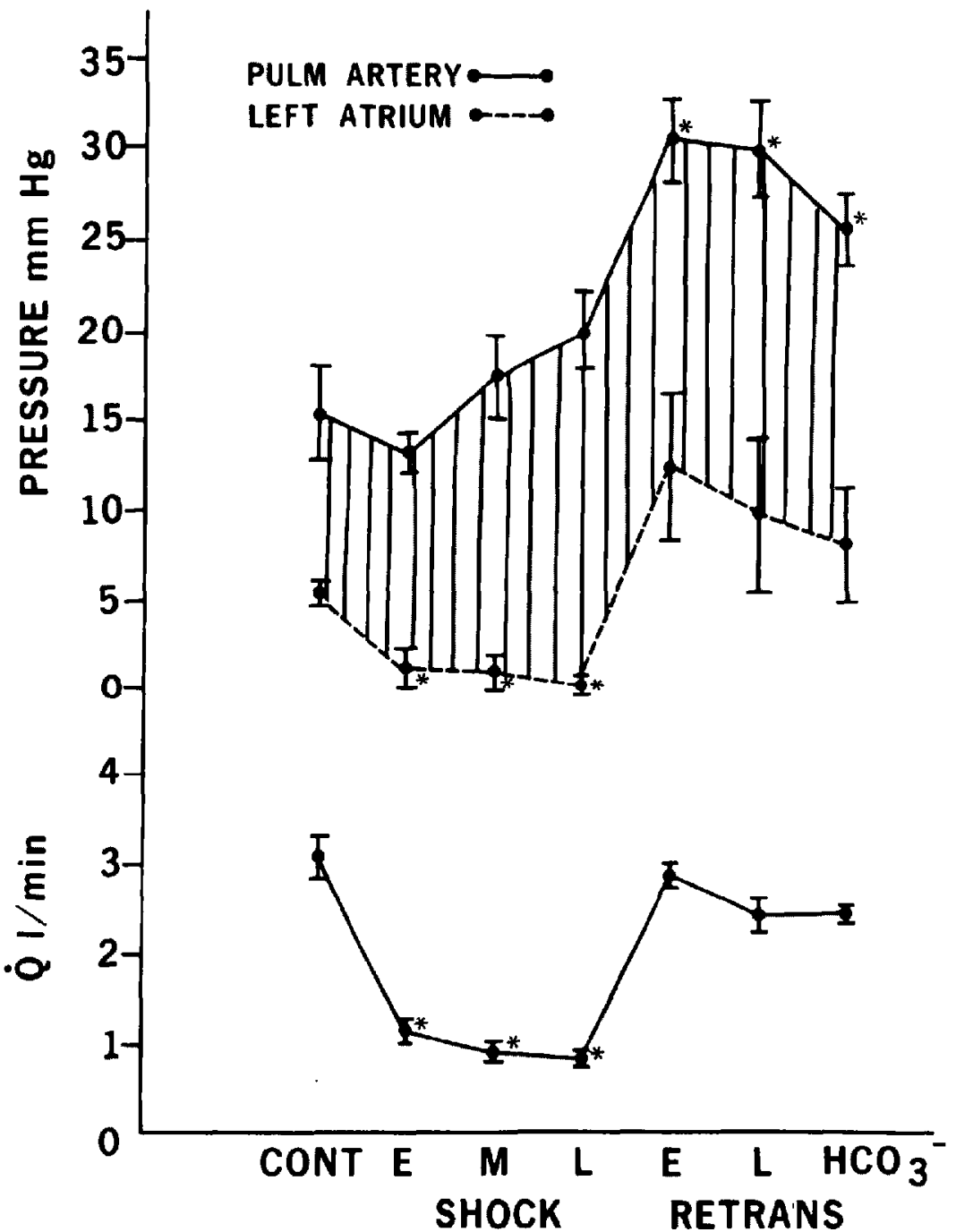

Ficune 1. Pulmonary artery pressure, left atrial pressure and cardiac output values (mean \pm 1 S.E.M.) at the indicated times of the experiment in the control group of dogs (no drugs) CONT is control results, followed by early (E), middle (M) and late (L) results during the period of haemorrhagic shock, followed by early (E) and late (L) results as removed blood was retransfused, followed by results after $\mathrm{NaHCO}_{3}$ was infused $\left(\mathrm{HCO}_{3}^{-}\right)$to correct the metabolic acidosis that developed during shock. The hatched area indicates the changing PA to left atrial pressure gradient. ${ }^{\circ}$ Indicates significantly different from control (CONT) level.

not increase from control to after $\mathrm{NaHCO}_{3}$. In fact, the mean increase of $\mathrm{ETV}_{\mathrm{r}}$, was least in the dogs receiving intravenous A.S.A. when compared with the other groups ( Table IV).

In contrast to the control dogs, where both $\mathrm{VD} / \mathrm{VT}$ and $\mathrm{A}-\mathrm{aO} .2$ gradients rose from control to after $\mathrm{NaHCO}_{3}$, there were no changes in $\mathrm{VD} / \mathrm{VT}$ or $\mathrm{A}-\mathrm{aO} \mathrm{O}_{2}$ gradient in the A.S.A. dogs. $\mathrm{Pv}_{\mathrm{O}_{2}}$ decreased from control to after $\mathrm{NaHCO}_{3}$, as in the control 

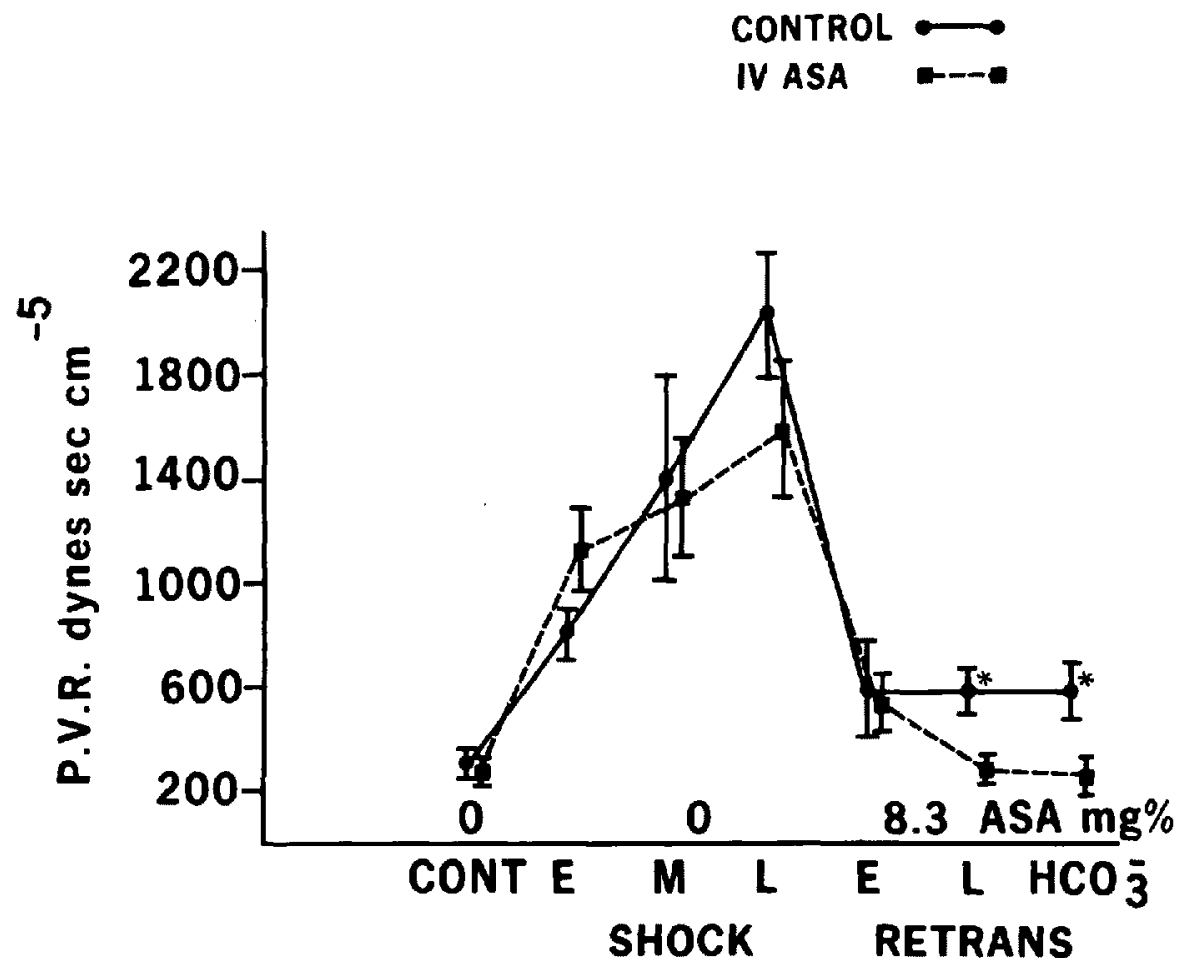

Figune 2. Pulmonary vascular resistance (PVR) values at the times of the experiment for the control "no drug" dogs and dogs that received A.S.A. at the end of the shock period (L shock) and before removed blood was retransfused (E RETRANS). "Indicates that mean PVR in the "no drug" group of animals is both significantly elevated above its own control value and also significantly elevated above the A.S.A. group of animals at the same time.

dogs (Table III) and stroke volume fell in the A.S.A. dogs (Table I). The platelet count did not change significantly in the dogs receiving A.S.A.

The salicylate levels were between $3.0 \mathrm{mg}$ and $8.6 \mathrm{mg}$ per cent at the end of the experiment with a mean of $5.75 \pm 0.75 \mathrm{mg}$ per cent.

\section{Chloroquine group}

The chloroquine group behaved similar to the "no drug" group until after blood was re-infused and $\mathrm{NaHCO}_{3}$ was given. PVR after the $\mathrm{NaHCO}_{3}$ infusion was not significantly different from PVR in the control period, but showed the highest mean increase of all the drug groups (Figure 3 and Table II). From control to after $\mathrm{NaHCO}_{3}$ there were no significant changes in pulmonary artery and left atrial pressures or $\dot{Q}$ ( Tables I and II). From control to after $\mathrm{NaHCO}_{3,}, \mathrm{Pv}_{\mathrm{O}_{2}}$ decreased (Table III), while $\mathrm{A}-\mathrm{aO}_{2}$ gradient rose $85.4 \pm 16.4$ per cent $(\mathrm{p}<0.025)$. At the same time there were no significant changes in VD/VT, stroke volume, or $\mathrm{ETV}_{\mathrm{I}}$. (Table I and Table IV).

The chloroquine group was the only one to show a significant reduction in platclet count from control to after $\mathrm{NaHCO}_{3}$.

The chloroquine levels ranged between 2 and $7 \mu \mathrm{g}$ per cent. 


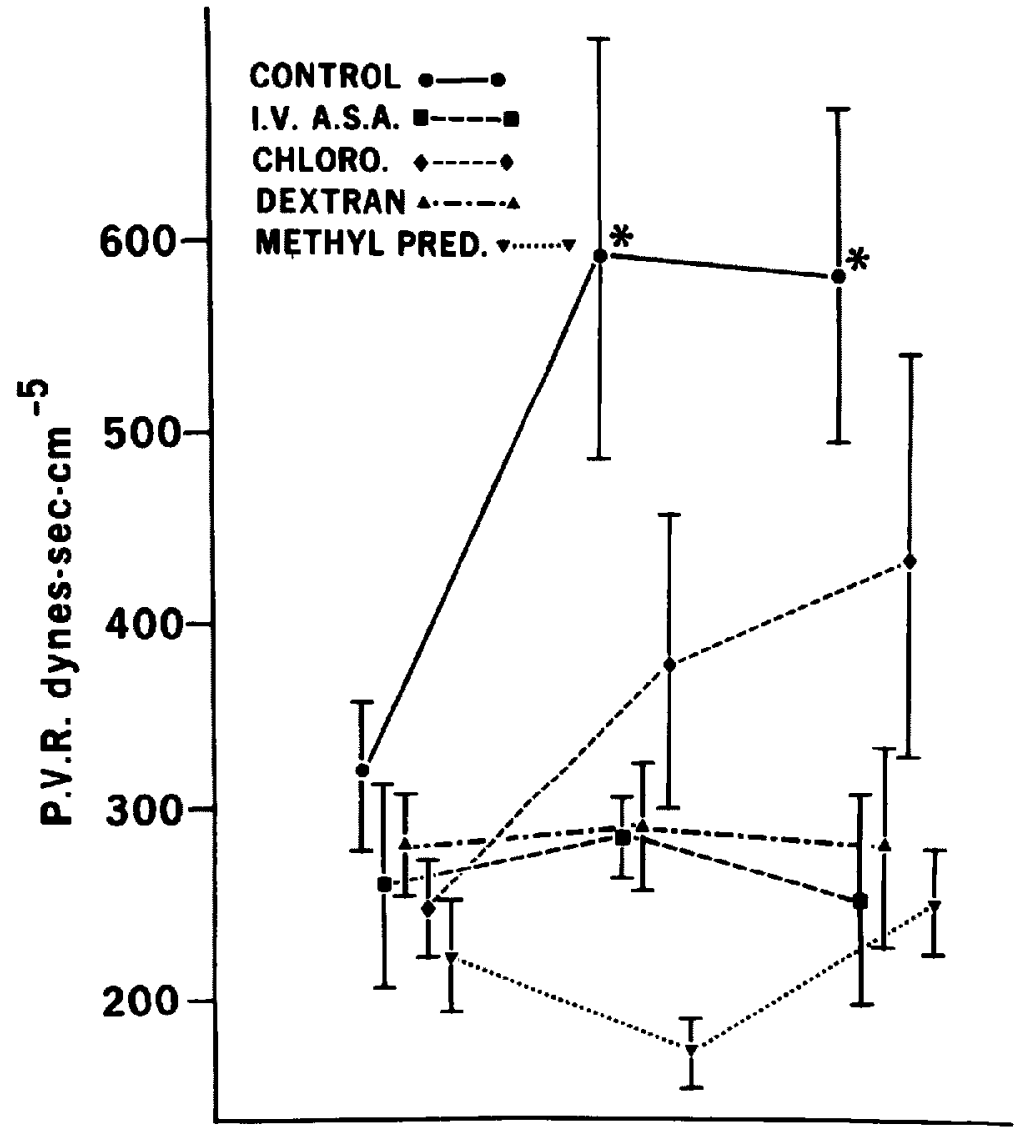

\section{PRESHOCK POSTSHOCK BICARB.}

Figure 3. PVR values for all groups of dogs in the control period (pre-shock), after all the removed blood was retransfused (post-shock) and after $\mathrm{NaHCO}_{3}$ was administered (BICARB). 'Indicates significantly different from pre-shock values.

TABLE IV

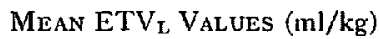

\begin{tabular}{lcrr}
\hline \hline & Control & After $\mathrm{HCO}_{3}{ }^{-}$ & \multicolumn{1}{c}{$\begin{array}{c}\text { Percentage } \\
\text { change }\end{array}$} \\
\hline No drug & $7.63 \pm 0.64$ & $9.90 \pm 1.19$ & $25.1 \pm 15.3$ \\
IV A.S.A. & $6.56 \pm 0.55$ & $\mathbf{7} .21 \pm 0.97$ & $9.8 \pm 16.3$ \\
Chloro & $8.12 \pm 1.41$ & $10.35 \pm 1.98$ & $29.7 \pm 16.7$ \\
Methylpred & $6.45 \pm 0.13$ & $7.62 \pm 0.22$ & $21.2^{*} \pm 3.6$ \\
Dextran & $6.26 \pm 0.67$ & $\mathbf{7 . 9 5} \pm 0.86$ & $32.8 \pm 17.4$ \\
\hline
\end{tabular}

*Indicates a significant change from control to after $\mathrm{HCO}_{3}$ times.

\section{Dextran group}

PVR in the control period was not significantly different from PVR after the $\mathrm{NaHCO}_{3}$ infusion (Tables I and II). Between the same times there were no significant changes in pulmonary artery and left atrial pressures or $\dot{Q}$ (Tables I and II). 
Gas exchange did not change between control and after $\mathrm{NaHCO}_{3} . \mathrm{Pv}_{\mathrm{O}_{2}}$ did not change (Table III). Mean ETV $\mathrm{I}_{\mathrm{J}}$ rose $32.8 \pm 17.4$ per cent (N.S.). Although it was not significant, the mean fall in platelet counts was the largest of any drug group (Table III). At least a portion of this was probably due to haemodilution as indicated by the significant reduction in haemoglobin levels ( $\mathrm{Hb}$, Table III). There were no other significant changes.

\section{Methylprednisolone group}

PVR in the control period was not significantly different from PVR after the injection of $\mathrm{NaHCO}_{3}$. Between these times there were no significant changes in pulmonary artery and left atrial pressures or $\dot{Q}$ (Tables I and II). There was a significant elevation in ETV $_{\mathrm{I}}$ ( Table IV). There were no other significant changes. Specifically, gas exchange did not change significantly. The smallest mean decrease in $\mathrm{Pv}_{\mathrm{O}_{2}}$ (N.S.) occurred in the methylprednisolone group between the control period and after $\mathrm{NaHCO}_{3}$ (Table III).

\section{Coagulation results}

A similar pattern of a disseminated intravascular coagulopathy (D.I.C.) was present in all groups of dogs. After shock there was prolongation of the prothrombin time and partial thromboplastin time with the appearance of fibrin degradation products (Figure 4). The individual coagulation factors decreased, compatible with a diffuse intravascular coagulopathy (Figure 4). In vitro platelet aggregation with ADP and epinephrine stimulation was reduced 50 per cent after chloroquine administration and was absent after intravenous A.S.A. and dextran. Platelet counts had a wide scatter. This may account for the lack of significant changes during the experiment.

\section{Discussion}

In a previous study we found that PVR and lung water increase in both pigs and dogs after two hours of haemorrhagic shock and blood retransfusion. ${ }^{2}$ Increases of PVR do not necessarily mean that pulmonary vessels are obstructed or constricted. A reduction in $\dot{Q}$ would increase PVR (equation 1). We found that during shock, PVR increases (Figure 2) as $\dot{Q}$ falls (Figure 1). It is apparent in Figure 1 that $\dot{Q}$ continues to fall from early to late shock, which should increase PVR 36.5 per cent if the PA-LA gradient remained constant. But PVR increased much more than 36.5 per cent from early to late shock (Figure 2). Figure 1 also illustrates the widening PA-LA pressure gradient during shock which accounts for 85 per cent of the increased PVR and indicates that pulmonary vessels are being closed, constricted or obstructed. After blood is re-infused and $Q$ returns to control values, PVR should also return to control value if a changing $Q$ is the only reason for the elevated PVR. In the control dogs PVR remained significantly elevated after shock was corrected, while $\dot{Q}$ returned to control values (Figure 1 and Figure 2) indicating that pulmonary vessels remained constricted or obstructed after shock. There was no relationship between the $\mathrm{pH}$ changes and PVR, and PVR did not fall when $\mathrm{NaHCO}_{3}$ was infused to correct the metabolic acidosis of shock (Figures 2 and 3). The changes in PVR did not result from handling of the blood because the 

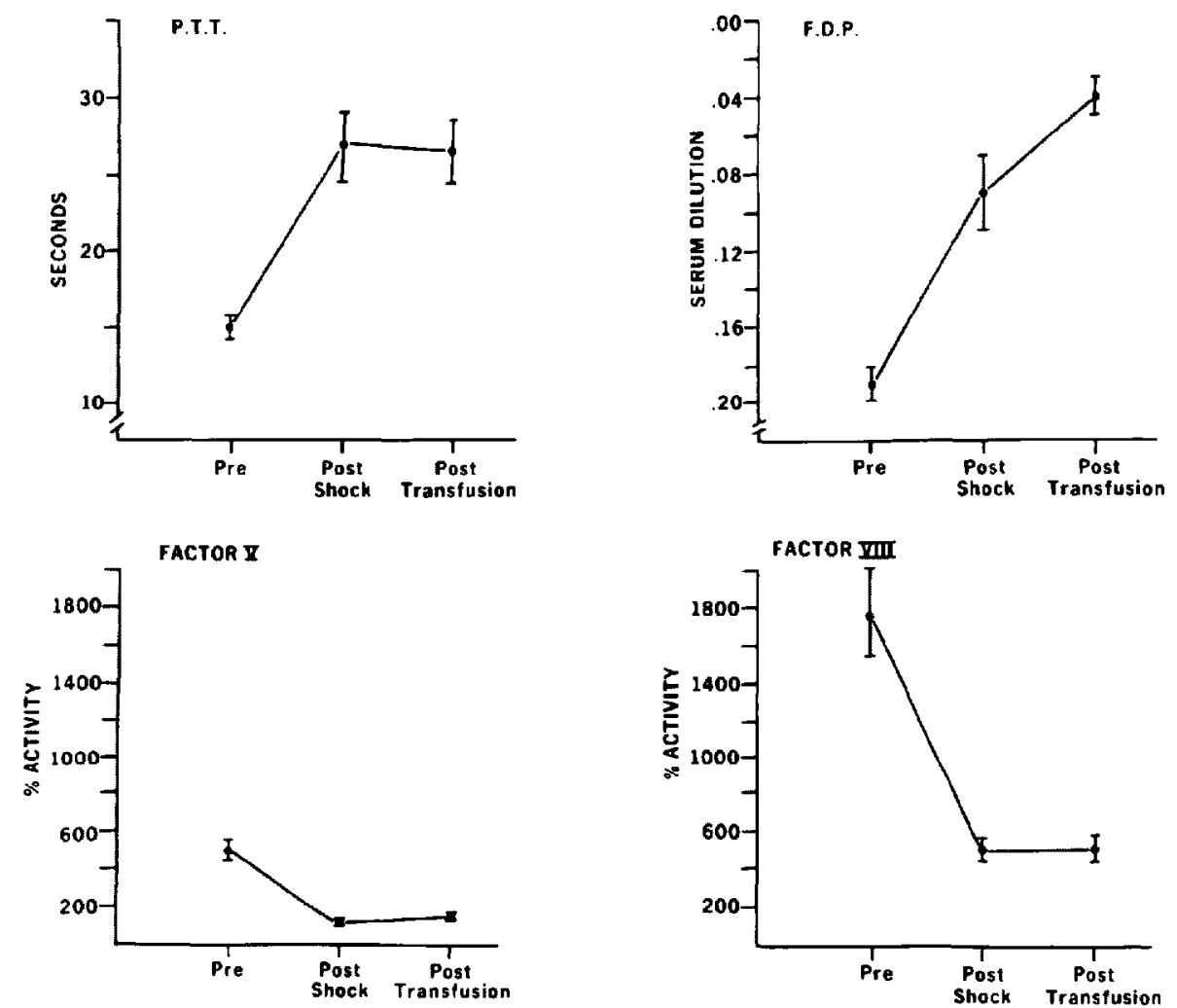

Ficure 4. Coagulation changes for all groups of dogs in the control period (pre-shock), at the end of the shock period (post-shock), and after blood reinfusion and $\mathrm{NaHCO}_{3}$ was infused (posttransfusion). P.T.T. is partial thromboplastin time and F.D.P. is fibrin degradation products.

time the blood was outside the animal was too short ${ }^{27}$ and storing dog blood does not create aggregates. ${ }^{28,20}$

In all of the treated groups PVR increased during shock and returned toward control levels after blood was re-infused. In contrast to the control group, none of the treated groups had a significant elevation in PVR at the end of the experiment. The mean increases in PVR by the end of the experiment were: control groups 95 per cent (significant), chloroquine group 77 per cent (N.S.), methylprednisolone group 14 per cent (N.S.), A.S.A. group -3.4 per cent (N.S.), and dextran group -2.9 per cent (N.S.). The A.S.A. group had a significant reduction in $\dot{Q}$ at the end of the experiment (Tables I and II). This should have increased calculated PVR. That the A.S.A. group had a slight decrease in PVR indicates that pulmonary vessels were neither obstructed nor constricted. This also applies to the dextran group. PVR changes in the chloroquine group did not differ significantly either from the control or treated groups (Tables I and II). Methylprednisolone had an intermediate effect in reducing the PVR increase to 14 per cent after haemorrhagic shock.

Since dextran and A.S.A. are the only drugs used which inhibited platelet aggregation and their use was not associated with an increase in PVR, platelets 
may play a role in the pulmonary vascular changes seen after haemorrhagic shock. Platelet aggregates have been demonstrated in cat and dog lungs after haemorrhagic shock. ${ }^{1,8-5}$ Platelet aggregates have also been observed in dog and monkey lungs after endotoxin-induced shock ${ }^{8,11,30}$ and shock created by traumatising the hind limbs of dogs. ${ }^{6,16}$ The question remains whether these platelets cause obstruction or whether substances the platelets release cause vasoconstriction of pulmonary vasculature and increase PVR. Papers by Radegran, et $a .^{31}$ (protamine induced platelet aggregation) and Bo and Hognestad ${ }^{32}$ (collagen induced platelet aggregation) both report that platelet aggregation increased PVR and that pulmonary vasoconstriction was more important than obstruction.

Presumably the haemorrhagic shock state induced platelet aggregation by stimulating epinephrine release, slowing blood flow and/or damaging some capillary beds so that platelets could contact collagen. ${ }^{33}$ As soon as platelets aggregate they release serotonin and prostaglandins. ${ }^{34,35}$ During shock some platelet aggregates would be filtered in the lung., ${ }^{1,3-5}$ This and/or the vasoconstrictors they release should increase PVR. When blood is re-infused at the end of the shock period, platelet aggregates and released substances would be flushed to the lungs and would maintain the high PVR. But dextran and A.S.A. do not deaggregate platelets. How, then, can they still reduce PVR when they are given after haemorrhagic shock? Since these drugs were given after the period of shock, and presumably after platelet aggregation, we are left with the following mechanisms of action; (a) they may prevent further platelet aggregation and release, since the effects of shock in stimulating epinephrine and damaging capillary beds continues in the post shock period; (b) dextran and A.S.A. may be protecting the lungs from the effects of substances released by platelets ${ }^{31,32,36}$; $(c)$ the effects may not be related to platelet changes but to other factors such as membrane stability, perfusion of ACD blood, or leukocyte trapping ${ }^{3,11,37}$ in the lungs.

Saldeen $^{38}$ reports finding fibrin microemboli in the lung and pulmonary oedema in dogs injected with thrombin and a fibrinolytic inhibitor (AMCA). He suggests plasminogen activation inhibitors and fibrin degradation products are important in creating progressive pulmonary dysfunction after trauma. Pulmonary damage was not prevented with an antihistamine (mepyramine and maleate), antiserotonins (methysergide, reserpine), anti-prostaglandins (A.S.A., indomethacin, polyphloretin phosphate), anti-inflammatory agents (methylprednisolone, calcium), or an anti-adrenergic agent (phenoxybenzamine). Dextran reduced fibrin accumulation in the lungs. There is value in reconciling the lack of benefit of A.S.A. in Saldeen's work with the benefit of A.S.A. found in ours. Saldeen states that he is discussing a "delayed microembolism syndrome" 38 and uses "pulmonary damage" as his end point. They find ${ }^{30}$ that the worst lung lesion is produced by thrombi and antifibrinolysins, regardless of the platelet count. Since the animals treated with infusions of thrombin and antifibrinolysins developed severe hypoxaemia $\left(\mathrm{Pa}_{\mathrm{O}_{2}}<50 \mathrm{~mm} \mathrm{Hg}\right.$ ) with both a respiratory acidosis $\left(\mathrm{Pa}_{\mathrm{CO}_{2}} 48 \mathrm{~mm} \mathrm{Hg}\right)$ and metabolic acidosis (B.E. $-15.6 \mathrm{mEq} / 1$ ) within 2.5 hours of the infusion, the lung lesion created is obviously much greater than that created by our haemorrhagic shock stimulus. ${ }^{2}$ Any embolus to the lung could create these changes and the question remains whether the artificial stimulus of thrombin and antifibrinolysin administration mimics the lung lesion created by haemorrhagic shock. We would 
suggest that PVR may first be elevated after haemorrhagic shock by platelets or their release substances and that the fibrin microembolus or thrombus only becomes a problem later. Radegran ${ }^{40}$ found as we did that PVR was reduced by A.S.A. (Table II). A consumption coagulopathy was present in our dogs and was unaffected by A.S.A. We conclude that A.S.A. was of real benefit to the lung lesion created by haemorrhagic shock.

The drugs used in this experiment may each have its own mechanism of action or combinations of mechanisms. Methylprednisolone also reduced the increase of PVR after shock. This effect could be mediated through platelet preservation, leukocyte changes, membrane stability, ${ }^{41}$ reduction in pulmonary venous constriction, ${ }^{42}$ or reduced prostaglandin release. ${ }^{48}$ In summary, if only one mechanism of action is working, membrane stabilization either at platelet or capillary membranes could explain the effects of A.S.A., dextran and methylprednisolone in reducing the PVR elevation found after haemorrhagic shock.

The "no drug" group did not have a significant increase in ETV $_{\mathrm{L}}$ while a previous "no drug" group did have. ${ }^{2}$ Since the ETV $\mathrm{L}_{\mathrm{L}}$ changes were directionally similar we conclude that the lack of significance found in this experiment was due to the smaller number of dogs ( 5 as opposed to 26). This criticism must also apply to the drug groups where larger numbers of dogs might show statistically significant changes in $\mathrm{ETV}_{\mathrm{L}}$. The order of severity of increases in ETV $\mathrm{V}_{\mathrm{r}}$ (A.S.A. group 9.8 per cent, methylprednisolone group 21 per cent, "no drug" group 25 per cent, chloroquine group 30 per cent and dextran group 33 per cent (Table IV) can only be taken as suggestive of the order if larger numbers of dogs were studied. However, the small increase in lung water in the A.S.A. group is more impressive if the significant elevation in pulmonary artery and left atrial pressure is kept in mind (Tables I and II). ETV , changes did not relate to PVR changes in these experiments.

$\mathrm{VD} / \mathrm{VT}$ and $\mathrm{A}-\mathrm{aO}_{2}$ gradients rose significantly in the control dogs. A portion of the VD/VT increase is due to the increased respiratory frequency of these dogs after shock. The $\mathrm{A}-\mathrm{a} \mathrm{O}_{2}$ and respiratory frequency changes are compatible with interstitial oedema in the lungs. ${ }^{44}$ The only significant rise in these parameters in the drug treated animals was the elevated $\mathrm{A}-\mathrm{aO} .$. gradient in the chloroquine dogs. Although none of the dogs became hypoxaemic or hypercarbic these findings would suggest some protection of the lungs conferred by A.S.A., dextran and methylprednisolone given after shock.

Most dogs had an increase in mean LA pressure at the end of the experiment, although only the A.S.A. group had a significant elevation. Stroke volume fell in the A.S.A. and control groups. Since these changes occurred when afterload was not increased, this would suggest a reduced myocardial performance in control and A.S.A. groups. Although not significant, methylprednisolone (11.5 per cent) and dextran (13.5 per cent) groups increased their stroke volumes suggesting that dextran and methylprednisolone may help to maintain myocardial performance after shock. Although there are other possible explanations for the $\mathrm{Pv}_{\mathrm{n}_{2} .}$ results, dextran and methylprednisolone groups had the smallest fall in $\mathbf{P v}_{\mathbf{O}_{2}}$ from the control period to after the injection of $\mathrm{NaHCO}_{3}$. This may result from maintained myocardial performance when these drugs are used in shock.

While platelet aggregation was reduced by chloroquine and prevented by 
intravenous A.S.A. and dextran the coagulopathy of the control shock dogs could not be prevented by any of the drugs used in this experiment.

\section{SUMMARY}

We have described increases in lung water and pulmonary vascular resistance and reduced myocardial performance in both pigs and dogs after two hours of haemorrhagic shock followed by re-infusion of blood. In this experiment haemorrhagic shock was induced by removing blood to ACD blood packs in five groups of dogs. After two hours of shock, blood was re-infused and $\mathrm{NaHCO}_{3}$ was given to correct the metabolic acidosis of shock. One group of dogs remained as control and received no drugs. Experiments were carried out on three other groups of dogs with one of aspirin, dextran and methylprednisolone given intravenously at the end of the shock period and before blood was re-infused. To allow absorption, chloroquine was given intramuscularly before the period of shock in the fifth group of dogs. In the group with no drugs pulmonary vascular resistance (PVR) increased 95 per cent (significant) from the control period to the end of the experiment. PVR in the control period was not significantly different from PVR at the end of the experiment in any drug group. However, chloroquin was associated with the greatest increase in PVR between these times ( 77 per cent N.S.). PVR actually fell from control levels to the end of the experiment in both the aspirin $(-3.4$ per cent N.S.) and dextran ( -2.9 per cent N.S.) groups. PVR rose (14 per cent N.S.) from the control period to the end of the experiment in the methylprednisolone group. The aspirin, dextran and methylprednisolone PVR results are all significantly different from the "no drug" group. In both the aspirin and dextran groups platelet aggregation was inhibited. Only the methylprednisolone group had a significant increase in lung water ( 21 per cent) and the smallest increase in lung water occurred in the aspirin group ( 9.8 per cent N.S.). We could not relate lung water changes to PVR changes. The lung water changes were compatible with interstitial pulmonary oedema and did not lead to serious gas exchange problems. Myocardial performance appeared improved with dextran and methylprednisolone after shock.

We conclude that while dextran and methylprednisolone confer some benefit in preventing increases in PVR and lung water after haemorrhage shock, aspirin is the best drug of those studied in preventing these changes.

\section{RÉSUMÉ}

Nous avons montré dans des travaux antérieurs chez des chiens et des porcs qu'un choc hémorragique suivi d'une réinfusion du volume saigné provoquait une augmentation de l'eau pulmonaire extravasculaire et de la résistance vasculaire pulmonaire; de plus, le phénomène était associé à une diminution de l'efficacité myocardique.

Dans cette expérience-ci, nous avons à nouveau produit un choc hémorragique 
en saignant des chiens et en les maintenant à une pression artérielle moyenne de $50 \mathrm{~mm} \mathrm{Hg}$ durant deux heures, après quoi le sang versé était retourné à l'animal et l'on corrigeait, à l'aide de bicarbonate, l'acidose métabolique résultant de la période de choc.

L'expérience a porté sur cinq groupes d'animaux: un premier, servant de témoin, n'a reçu aucun médicament à la suite de la réinfusion du sang versé; les groupes deux, trois, quatre et cinq reçurent respectivement de l'acide acétylsalicylique, de la chloroquine, du dextran, de la méthylprednisolone. Le médicament était administré par voie veineuse avant la réinfusion du sang, sauf pour les animaux du groupe trois où la chloroquine était administrée par voie intramusculaire avant la création du choc pour en assurer l'absorption.

Résultats: Chez le groupe témoin, on a observé une augmentation de 95 pour cent de la résistance vasculaire pulmonaire après la réinfusion et la correction de l'acidose; ce phénomène ne s'est pas manifesté de façon significative chez les animaux traités des quatre autres groupes où les résistances vasculaires pulmonaires observées en fin d'expérience n'étaient pas significativement différentes de celles observées au cours de la période de contrôle.

Ainsi, chez les animaux traités à l'acide acétylsalicylique et au dextran, la résistance vasculaire pulmonaire était plus basse en fin d'expérience par rapport aux chiffres observés en période de contrôle ( 3.4 pour cent et 2.9 pour cent respectivement, valeurs non significatives); de même, une élévation non significative de 14 pour cent par rapport au groupe contrôle a été observée en fin d'expérience chez le groupe ayant reçu de la méthylprednisolone. D'autre part, les valeurs de la résistance vasculaire pulmonaire des groupes deux, quatre et cinq (acide acétylsalicylique, dextran, méthylprednisolone) différaient de façon significative de celles observées chez le groupe témoin.

Ce sont les animaux du groupe traité à la chloroquine qui ont présenté la plus grande élévation de la résistance vasculaire pulmonaire en cours d'expérimentation ( 77 pour cent non significatif).

L'agrégation plaquettaire était inhibée chez les animaux des groupes deux et quatre (acide acétylsalicylique, dextran).

De tous les chiens traités, seuls ceux du groupe cinq (méthylprednisolone) ont montré une augmentation significative ( 21 pour cent) de l'eau pulmonaire extravasculaire. La plus faible augmentation ( 9.8 pour cent non significatif) a été observée chez les animaux du groupe deux (acide acétylsalicylique). Nous n’avons pu mettre en évidence de corrélations entre les changements de l'eau pulmonaire et la résistance vasculaire pulmonaire. Les modifications observées étaient compatibles avec un oedème pulmonaire interstitiel et n'ont pas amené de problèmes sérieux au plan des échanges gazeux.

La fonction myocardique semblait améliorée après le choc chez les animaux traités au dextran et chez ceux traités à la méthylprednisolone.

Nous concluons que l'acide acétylsalicylique, le dextran et la méthylprednisolone concourent à prévenir l'augmentation de la résistance vasculaire pulmonaire et l'augmentation de l'eau pulmonaire extravasculaire après un choc hémorragique, cependant l'acide acétylsalicylique s'est montrée, dans ce domaine, le meilleur des agents étudiés. 


\section{ACKNOWLEDGEMENTS}

We thank these technicians for their invaluable help: J.C. Kay, N. Bell, G. Carmichael, G. Caskanette, S. Slack, and C. Martin. Pentobarbitone was supplied by Ayerst, Rheomacrodex by Pharmacia, and Aspegic by Labatoire Egic. We thank C. Mindorff for help with the manuscript preparation and Dr. J. Obdrzalek for his critical review. We thank the departments of medical art and photography at St. Michael's Hospital for their help.

This work was supported by grants from the Canadian Thoracic and Respiratory Disease Association, The Medical Research Council of Canada and the St. Michael's Research Society.

\section{REFERENCES}

1. Bo, G. \& Hocnesrad, J. Thrombocytes and pulmonary vascular resistance. Microcirculatory approaches to current therapeutic problems. Symposia, 6th Europ. Conf. Microcirculation, Aalborg 1970, pp. 32-34 (Karger, Basch 1971).

2. Noble, W.H. Early changes in lung water after hemorrhagic shock in pigs and dogs. Can. Anaesth. Soc. J. 22: 39-49 (1975).

3. Connelt, R.S., SWAnk, R.L., \& WEbB, M.C. The development of pulmonary ultrastructural lesions during hemorrhagic shoek. J. of Trauma 15: 116-129 (1975).

4. Goodman, J.R., Lise, R.C., Blaisdell, F.W., Hale, A.D., \& Thomas, A.N. Pulmonary microembolism in experimental shock. Am. J. of Pathol. 52: 391-400 ( 1968 ).

5. LJungquist, U.E. \& SChwartz, S.I. Pulmonary platelet trapping during shock and pulmonary embolus. J. of Surg. Res. 18: 559-565 (1975).

6. Bercentz, S.E., Lewis, D.H., \& LJungeuist, U. Trapping of platelets in the lung after experimental injury. Microcirculatory approaches to current therapeutic problmes. Symposia 6th Europ. Conf. Microcirculation, Aalborg 1970, pP. 35-40 (Karger, Basel, 1971).

7. Rовв, J. The role of microembolism in the production of irreversible shock. Ann. Surg. 158: 685-692 (1963).

8. McKay, D.G., Margaretten, W., \& Csavossy, I. An electron microscope study of endotoxin shock in rhesus monkeys. Surg. Gynecol. Obstet. 125: 825-832 (1967).

9. Moss, G.S., Das Gupta, T.K., Newson, B., \& Nyhus, L.M. Morphological changes in the primate lung after hemorrhagic shock. Surg. Gynecol. Obstet. 134: 3-9 (1972),

10. Pulmonary effects of non-thoracic trauma. Proceedings of a conference conducted by the committee on Trauma, Div. of Med. Sci., Nat. Acad. of Sci., Nat. Res. Council, J. of Trauma. Vol. 8 (1968).

11. Depalma, R., Coil, J., Davis, J., \& Holden, W. Cellular and ultrastructural changes in endotoxenia: a light and electron microscopic study. Surgery, 62: 505 (1967).

12. Shoemaken, W.C. Pattern of pulmonary hemodynamic and functional changes in shock. The lung in the critically ill patient. Baltimore, Williams \& Wilkins Co., pp. 33-43 (1976).

13. Poncelli, R., Foster, W.M., Bercofsky, E.H., Bicker, A., Kaur, R., Demeny, M., \& REICH, T. Pulmonary circulatory changes in pathogenesis of shock lung. Amer. J. of Med. Sci. 268: 250-261 (1974).

14. Coox, W.A. Experimental shock lung model. J. Trauma 8: 793 ( 1968 ).

15. Famewo, C.E., Noble, W.H., \& Carvey, M.B. Use of aspirin in hemorrhagic shock. Can. Anaesth. Soc. J. 22: 50-60, 1975.

16. Peer, R.M. \& Schwartz, S.I. Prevention of pulmonary platelet trapping following trauma. Surgical forum 224: 5-7 (Abst.) (1973).

17. Poller, L. Recent advances in thrombosis. Edinburgh, Churchill-Livingston Co. Ch. 7 (1973).

18. WEISs, J.A. The effects of clinical dextran on platelet aggregation, adhesion and ADP release in man; in vivo and in vitro studies. J. Lab. Clin. Med. 69: 37-46 (1967).

19. Famewo, C.E., Nonle, W.H., \& Garyey, M.B. Use of chloroquine in shock. Can. Anaes. Soc. J. 22: 687-695 (1975)

20. Noble, W.H. \& KAY, J.C. Cardiac catheterization in dogs. Can. Anaes. Soc. J. 21: 616-620 (1974). 
21. Noble, W.H. \& Severinchaus, J.W. Thermal and conductivity dilution curves for rapid quantitation of pulmonary edema. J. Appl. Physiol. 32: 770-775 (1972).

22. Noble, W.H., Ondnzalek, J., \& KaY, J.C. A new technique for measuring pulmonary edema. J. Appl. Physiol. 34: 508-512 (1973).

23. Nunn, J.F. Applied respiratory physiology, 1st ch. 9: pp. 244, London: Butterworths (1969).

24. Kuwadara, S. \& Duncalf, D. Effect of anatomical shunt on physiologic deadspace-totidal volume ratio: a new equation. Anaesthesiology 31: 575-577 (1969).

25. McKenzie, N., Heimbecker, R.D., Barnicoat, R.A., \& Gergely, N.F. Bloodless openheart surgery with atraumatic extra-corporeal circulation. C.M.A.J. 112: 1073-1077 (1975).

26. Snedecor, G.W. \& Cochran, W.G.: Statistical methods. Iowa State Univ. Press, U.S.A (1967).

27. Ceelhoed, G.W. \& Bennett, S.H. Effect of filtration and aged-cell separation in "shock lung" resulting from stored blood perfusion. Surgical forum 24:7-9 (1973).

28. Bennett, S.H., Geelhold, G.W., Aaron, R.K., Solis, R.T., \& Hoye, R.C. Pulmonary injury resulting from perfusion with stored bank blood in the baboon and dog. J. Surg. Res. 13: $295-306$ (1972).

29. Davimson, I., Barnetr, J.A., Miller, E., \& Litwin, M.S. Pulmonary microembolism associated with massive transfusion. Am. Surg. $181 ; 51-57$ (1975).

30. Gelin, L.E. Discussion. Am. Surg. 182: 226 (1975).

31. Radecran, X., Bergentz, S.E., Lewis, D.H., Ljuncvist, U., \& Olsson, P. Pulmonary effects of induced platelet aggregation. Intravascular obstruction or vasoconstriction? Scand. J. Clin. Lab. Invest. 28: $423-427$ (1971).

32. Bo, G. \& HocNestad, J. Effects on the pulmonary circulation of suddenly induced intravascular aggregation of blood platelets. Acta. Physiol. Scand. 85: 523-531 (1972).

33. Wilner, G.D., NAssel, H.L., \& LERuy, E.C. Aggregation of platelets by collagen. J. Clinical Investig. 47: 2616 (1968).

34. Klarze, J. Prostaglandins and platelet aggregation. M: Schettler G. (ed.). Platelets and the vessel wall; fibrin deposition. Symposium of the European Atherosclerosis Group. June 15-17, 1969. Georg Thieme Virlag Stuttgart, pp. 54 (1970).

35. KLOEN, J. Relationship between chemical structure and platelet aggregation activity of prostaglandins. Biochem. Biophys. Acta. pp. 187-285 (1969).

36. RÁDECRAN, K. Circulatory and respiratory effects of induced platelet aggregation. An experimental study in dogs. Acta Chirurgica Scandinavica Suppl. 420 (1971). Vol. 419-429, pp. 3-24 (1972).

37. Wilson, J.W., Ratliff, N.B., Younc, W.G., Hackel, D.B., \& Mukar, E. Changes in the morphology of leukocytes trapped in the pulmonary circulation during hemorrhagic shock. In: Microcirculatory approaches to current therapeutic problems. Symposiums, 6th Europ. Conf. for Microcirculation. Ahlborg, pp. 41-48 (1970). Basel, Switzerland: S. Karger (1971).

38. SaldeEN, T. Trends in microvascular research: the microembolism syndrome. Microvasc. Res. 11: 227-259 (1976).

39. Busch, C., Lindquist, O., \& SaldeEn, T. Respiratory insufficiency in the dog induced by pulmonary microembolism and inhibition of fibriolysis. Acta Chir. Scand. 140: 255-266 (1974).

40. RAdecran, $K$. The effect of acetylsalicylic acid on the peripheral and pulmonary vascular responses to thrombin. Acta Anaesth. Scand. 16: 140-146 (1972).

41. Wrison, J.W. Treatment or prevention of pulmonary cellular damage with pharnacologic doses of corticosteroid. 134: 675-681 (1972).

42. KUSAjIMA, K., WAX, S.D., \& WEBB, W.R. Effects of methylprednisolone on pulmonary microcirculation. Surg. Gynecol. Obstet. 139: 1 (1974).

43. Grylewski, R.I., Panczenko, B., Konbut, R., Grodzinska, L., \& Ocetriewicz, A. Corticosteroids inhibit prostaglandin release from perfused mesenteric blood vessels of rabbit and from perfused lungs of sensitized guinea pig. Prostaglandins 10:343-347 (1975).

44. Noble, W.H., Kovacs, K., \& KaY, J.C. Fine structural changes in haemodynamic pulmonary oedena. Can. Anaesth. Soc. J. 21: 275-284 (1974). 